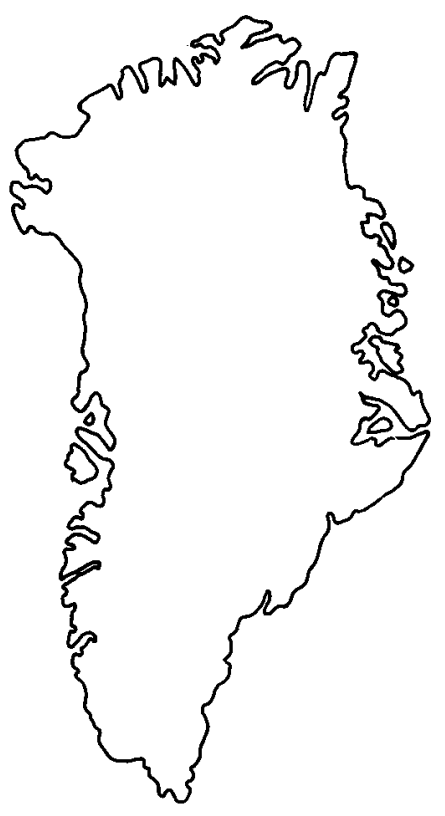

\title{
Volcanic marker horizons in the upper part of the Maligât Formation on eastern Disko and Nuussuaq, Tertiary of West Greenland: syn- to post-volcanic basin movements
}

\author{
Lotte Melchior Larsen and Asger Ken Pedersen
}

\begin{abstract}
Lavas from the Rinks Dal, Nordfjord and Niaqussat Members of the Maligât Formation overlying gneisses in eastern Nuussuaq are described together with an overlying young sequence of basalts not known from other areas. The Niaqussat Member lavas are the first recorded from Nuussuaq. On Disko lavas of the Nordfjord and Niaqussat Members have been found on the highest mountain tops bordering the Sermersuaq ice cap, and these two members are now known to have been present over the whole of Disko and eastern Nuussuaq. East of the Disko Gneiss Ridge the base of the Niaqussat Member forms a fairly smooth, gently south-easterly sloping surface that can be extrapolated to Nuussuaq. Eruption sites for the Nordfjord and Niaqussat Members are centred in western Disko, but feeder dykes east of the Disko Gneiss Ridge are indicated, especially for the Niaqussat Member in both Disko and Nuussuaq. There is evidence from several levels within the volcanic pile of relative subsidence in the south-east and uplift in the north-west, and these movements must have taken place in an extended period both during and after the volcanic activity.

L. M. L., Geological Survey of Greenland, $\emptyset_{\text {ster Voldgade 10, DK-1350 Copenhagen }}$ $K$, Denmark.

A. K. P., Geological Museum, Øster Voldgade 5-7, DK-1350 Copenhagen K, Denmark.
\end{abstract}

The investigation of the volcanic history of the early Tertiary lavas in the West Greenland Basin relies on the identification and mapping of marker horizons. We have earlier (Larsen \& Pedersen, 1990) described the distribution of volcanic marker horizons in the Rinks Dal Member in the lower part of the Maligât Formation on Nuussuaq and Disko, where a complex interplay between volcanic rocks in subaerial and subaqueous facies and non-volcanic clastic sediments was demonstrated.

Recent field investigations in high-lying areas on north-eastern Nuussuaq and central Disko extended into lava successions from the upper part of the Maligât Formation. The successions include characteristic sequences of silica-enriched sediment-contaminated lavas which can be recognised as parts of the Nordfjord and Niaqussat Members. These members overlie the Rinks Dal Member and were established in western Disko by Pedersen (1975); they were subsequently recorded from eastern Disko and south-eastern Nuussuaq where they constitute the top part of the Maligât Formation (Pe- dersen \& Larsen, 1987; Larsen \& Pedersen, 1989; Fig. 1). With the latest discoveries the Nordfjord and Niaquassat Members are now known to be present over an extensive region on Disko and Nuussuaq including large areas with high-lying basement east of some of the major faults delimiting the West Greenland Basin to the east. The Nordfjord and Niaqussat Members can therefore be used to analyse basin movements in the late- and post-volcanic stages.

This report describes some of the new ocurrences and gives an account of probable eruption sites east of the Disko Gneiss Ridge. Finally, it discusses some basin movements that can now be reconstructed.

\section{Maligât Formation in north-eastern Nuussuaq}

Plateau basalts from the Maligât Formation form the high ground north of Nunavik (Fig. 2). Access to the area is difficult because of the alpine topography with peaks reaching above $2000 \mathrm{~m}$ a.s.l., and extensive glaciation. Two profiles were sampled and $c .18 \mathrm{~km}$ of 


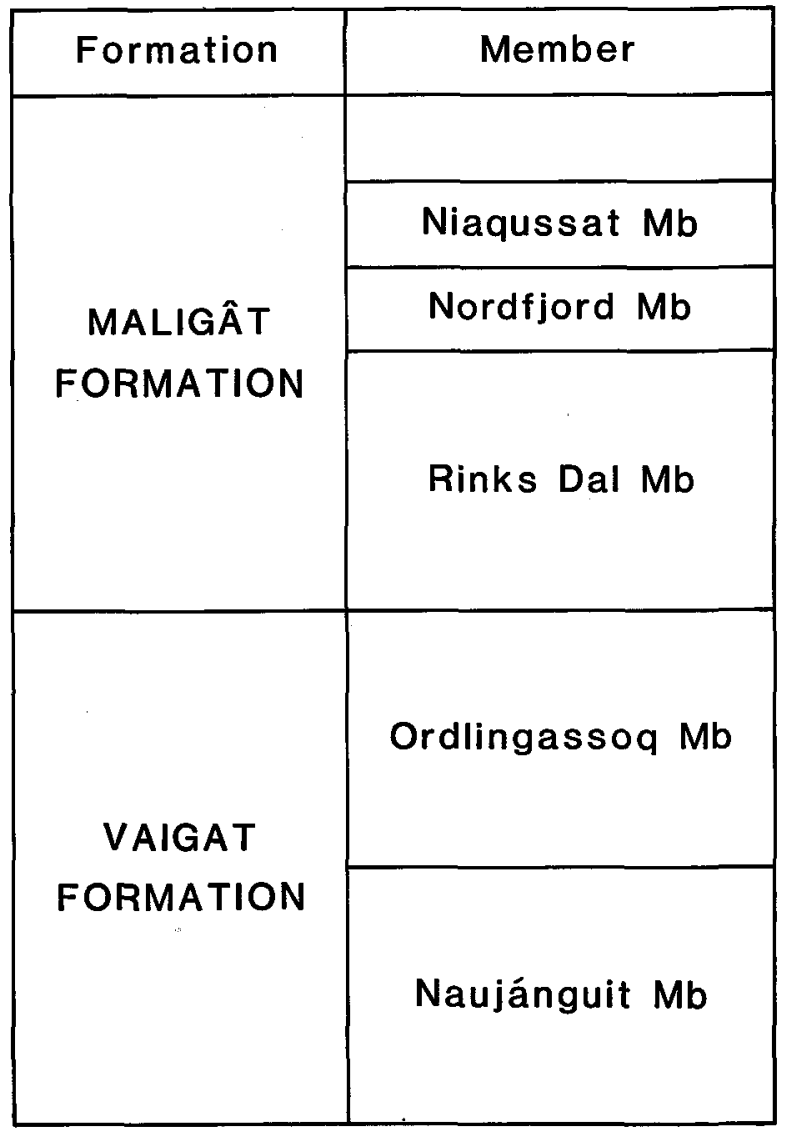

Fig. 1. Stratigraphy of the Tertiary volcanic succession on Disko and central and eastern Nuussuaq, established by Pedersen $(1975,1985)$.

mountain-sides were covered by colour stereo photographs during helicopter reconnaissance work. With quantitative photogrammetric measurements (Dueholm \& Pedersen, 1990) on these photographs still pending, the altitudes and thicknesses of the volcanic units given below are preliminary.

The volcanic succession in the area is underlain by Precambrian gneisses which in the Early Tertiary formed a palaeolandscape with a considerable relief and extensively weathered surfaces. The hilly gneiss landscape had a general slope towards the west to meet the low-lying areas with sediments and volcanics of the West Greenland Basin. From the west, the volcanic rocks of first the Vaigat Formation and later the Maligât Formation gradually lapped onto the gneiss landscape and eventually covered it.

In the investigated area north of Nunavik the Maligât Formation mostly rests directly on the gneisses. Up to $600-700 \mathrm{~m}$ of lavas are preserved but the thickness varies because of the uneven gneiss substratum. Fig. 3 shows the area between peaks $2000 \mathrm{~m}$ and $2020 \mathrm{~m}$ (Fig.
2). Three volcanic lithological units are apparent: a lower series of thick plateau lavas, a middle series of thin crumbly lavas with traces of sediments, and an upper series of plateau lavas. A composite profile through this sequence is shown in Fig 4. The lower series is identified as the Rinks Dal Member, whereas the middle series comprises lavas from both the Nordfjord and Niaqussat Members. The upper series is a hitherto unrecognised, young lava series.

\section{Rinks Dal Member}

The Rinks Dal Member comprises 5 to 7 lava flows with a combined thickness of $300-350 \mathrm{~m}$, resting on a partly weathered gneiss surface. The three lowest flows have prominent entablature zones and thin, very regular basal colonnades; the top zones are not oxidised. These features indicate that the lavas were emplaced in a distinctly wet environment. Similar features were observed in the Rinks Dal Member on eastern and southern Disko (Larsen \& Pedersen, 1990). The following lavas rest on lateritic soil, have no regular entablature zones and have red-oxidised top zones, indicating dry subaerial conditions of emplacement.

The basalts are all tholeiitic, with $1-5 \mathrm{~mm}$ plagioclase phenocrysts. A chemical analysis is presented in Table 1 (column 1).

\section{Nordfjord Member}

This member comprises one or perhaps two lava flows with a combined thickness of less than $50 \mathrm{~m}$. The lavas are tholeiitic, with up to $10 \mathrm{~mm}$ plagioclase laths. Between them occurs $c .1 \mathrm{~m}$ of reddish lateritised tuff. A chemical analysis of the upper lava is presented in Table 1 (column 2). The upper lava is followed by several metres of yellow-brown tuffaceous sediment; the upper part of this is dark brown and contains plant fossils.

\section{Niaqussat Member}

In the measured section (Fig. 4) two light greyish lavas are assigned to this member; however, further east up to five such flows are observed. The total thickness of the member is less than $50 \mathrm{~m}$. The lavas are of pahoehoe type and show distinct flow folding patterns. The lavas are olivine microporphyritic silicic basalts; chemical analyses are shown in Table 1 (columns 3 and 4). Both the lithology and the chemical composition are characteristic of the Niaqussat Member. Lavas from this member have not previously been identified on Nuussuaq. 


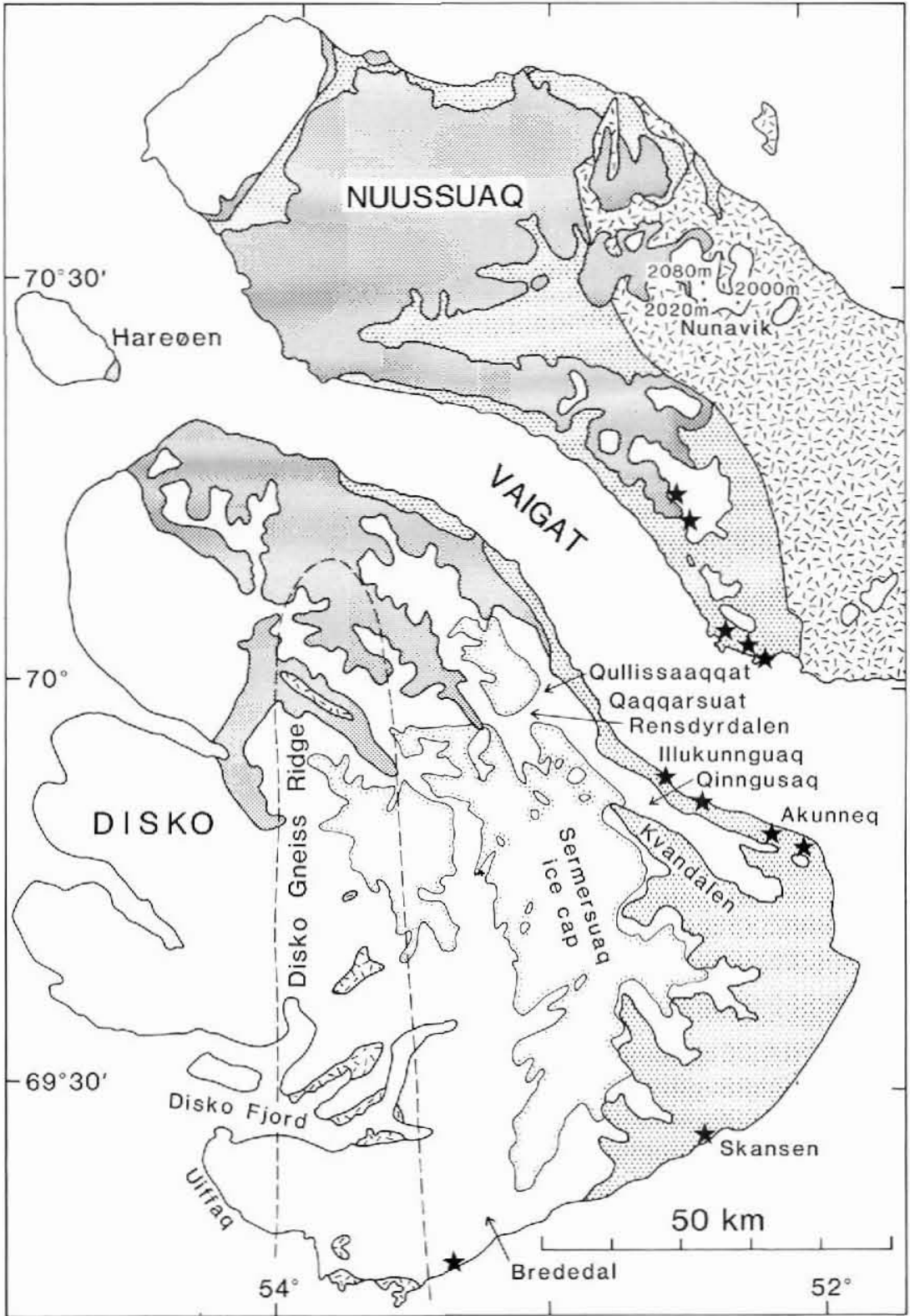

Fig. 2. Geological map of Disko and Nuussuaq. Also shown are occurrences of dykes correlated with the Niaqussat Member of the Maligât Formation east of the Disko Gneiss Ridge. Intrusions and eruption sites west of the ridge are not shown.

Overlying the unit is a horizon of orange brown sediment which has not been visited.

\section{Upper lava sequence}

About seven lava flows with a combined thickness of $200-250 \mathrm{~m}$ are preserved above the typical Niaqussat Member lavas. They are plagioclase-phyric to aphyric basalts.

The lowest lava is c. $50 \mathrm{~m}$ thick and is composed of several individual lava tongues with prominently developed entablature zones. There are traces of yellow- brown sediment on the top. The two overlying lavas have less prominent entablature zones, but their morphology still indicates emplacement on a humid surface. A several metres thick layer of lateritic soil which may derive from alteration of tuff is present on top of the fourth lava. The uppermost three lavas are distinctly subaerial with red oxidised flow tops and show no indications of a wet environment. The two uppermost lavas are evolved FeTi basalts (Table 1, column 6) whereas the lower lavas have chemical compositions that are fairly common in the Maligât Formation (Table 1. column 5). The lavas are not correlatable with any of 


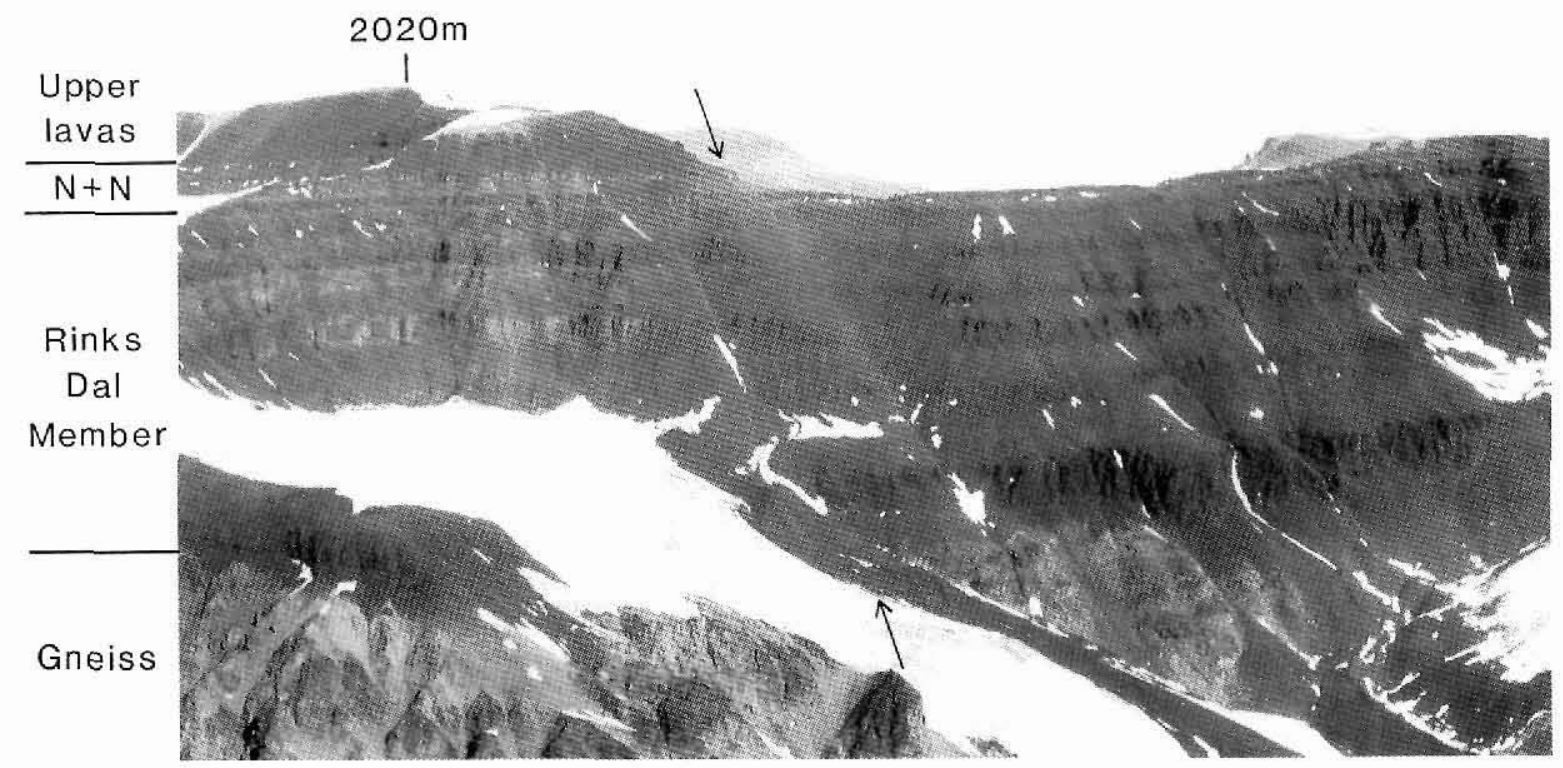

Fig. 3. The area between peaks $2000 \mathrm{~m}$ and $2020 \mathrm{~m}$ north of Nunavik, eastern Nuussuaq, viewed from the south. Weathered gneiss is overlain by lavas of the Maligât Formation in which three units can be distinguished as indicated. $\mathrm{N}+\mathrm{N}=\mathrm{Nordfjord}$ and Niaqussat Members. The lower part of the profile in Fig. 4 was measured between the arrows in the centre of the picture whereas the upper part of the profile in Fig. 4 was measured on peak $2080 \mathrm{~m}$ to the north of peak $2020 \mathrm{~m}$.

the lavas from the upper Maligât Formation and the overlying Hareøen Formation described from western Nuussuaq and Hareøen by Hald (1976).

\section{Nordfjord and Niaqussat Members in central and south Disko}

Earlier work on the Maligât Formation on Disko has demonstrated that the contaminated volcanic rocks from the Nordfjord and Niaqussat Members form valuable marker horizons in the western part of Disko (geological map sheets 1:100 000 Qutdligssat and Mellemfjord; Pedersen, 1977a, b). These markers are also found on some mountain tops in north-cast Disko, and Larsen \& Pedersen (1988) found that Niaqussat Member lavas are widespread on the mountains capping the Kvandalen region in east Disko. Larsen \& Pedersen (1989) described redeposited volcaniclastic sediments with rhyolite from the Nordfjord Member in north-east Disko. An unpublished photogrammetrical geological map which covers parts of south-west Disko (compiled by $F$. Ulff-Møller) indicates that contaminated lavas might be present on several plateau tops on the Uiffaq peninsula.

During recent field investigations along the western margin of the central ice cap (Sermersuaq) on Disko and on the Uiffaq peninsula emphasis was placed on locating the Nordfjord and Niaqussat Members. Two lithologies support the identification of lavas from these members even during brief helicopter landings on block fields. The most widespread and characteristic rock from the Nordfjord Member is a strongly porphyritic basalt with 5-10 mm large tabular plagioclase phenocrysts. The lavas of this rock type form pahoehoe flows, whereas most other feldspar-phyric lavas from the Maligât Formation tend to form aa flows. The most characteristic rock from the Niaqussat Member is a slightly olivine microporphyritic basalt which forms pahochoe lavas with flow folding and a characteristic inhomogeneity in the distribution of vesicles. Additionally, a one to several metres thick horizon of yellow-brown claystone often occurs at the base of the Nordfjord Member, and this member may also internally contain horizons with altered rhyolite tuff.

Lavas from the Nordfjord and Niaqussat Members were found at high altitudes east of the Disko Gneiss Ridge at many sites visited along the western margin of the Sermersuaq ice cap, from north-west of Rensdyrdalen to east of Brededal (Fig. 2). The members are absent along a N-S trending zone over most of the Disko Gneiss Ridge where the upper part of the Maligât Formation has been removed by erosion. In western Disko they are present at comparatively low altitudes because the areas west of the Disko Gneiss Ridge have 


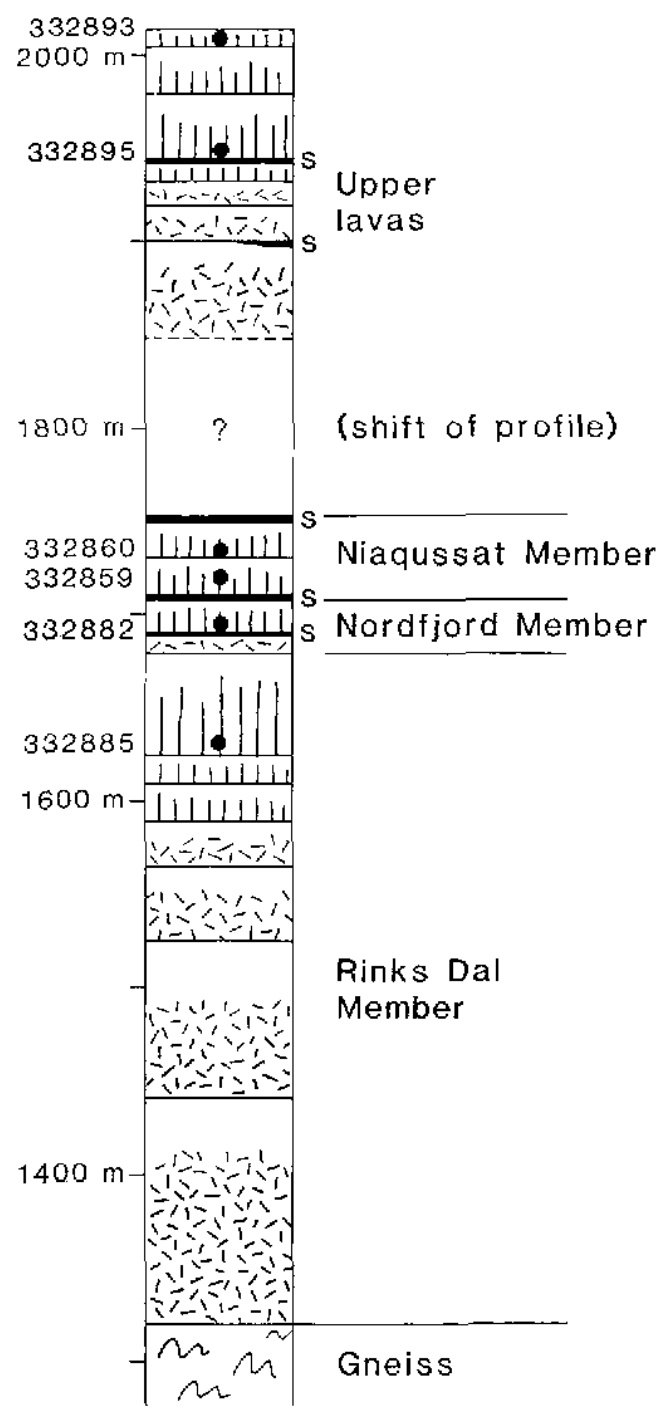

332885

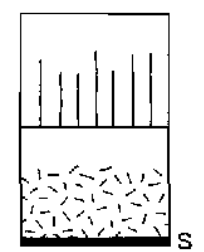

Analysis in Table 1

\section{Columnar - jointed lava \\ Entablature lava sediment / tuff}

Fig. 4. Composite profile through the Maligat Formation north of Nunavik, partly measured in the area slown in Fig. 3. Analyses of lasvas from this profile are given in Table 1 .

trecn downfaulted during post-volcanic tectonism affecting the continental margin.

On the Uiflag peninsula, lavas from the Nordfjord and Niaqussat Members cap the lava plateau at altitudes above $650-680 \mathrm{~m}$. They form a southern continuation of similar lava sequences exposed at the north coast of
Disko Fjord, in the downfaulted arcas west of the Disko Gneiss Ridge.

The new localities permit a stratigraphical correlation of the Nordfjord and Niaqussat Members across Sermersuaq and further to the east and north. The most recognisable, approximately isochronous surface, is the base of the Niaqussat Member. Fast of the Disko Gneiss Ridge the altitude of this surface can be contoured (Fig. 5). The contour pattern indicates a fairly smooth. gently south-easterly-sloping surface with mean dips just below $1^{\circ}$ in the north, decreasing to just below $0.5^{\circ}$ in south-east Disko. The localitics with Niaqussat or Nordfjord Members on Nuussuac seem, as a crude approximation, to fit onto a northern extension of this surface.

\section{Eruption sites for Nordfjord and Niaqussat Members}

In order to interprete the dynamics of the West Greenland Basin at the time when the upper Maligât Formation was formed, it is important to trace the distribution of eruption sites for the contaminated lavas of the Nordfjord and Niaqussat Members. Reports of eruption sites (craters), irregular intrusions and dykes of contaminated rocks from western and north-western Disko have been presented by Pedersen (1977b) and Ulff-M $\phi l l e r(1977,1983,1991)$, and contaminated dykes have been described from south-western Disko by Pedersen $(1977 \mathrm{c})$. These occurrences indicate that magma conduits and eruption sites are fairly widespread west of the Disko Gneiss Ridge. Data from east of the Gneiss Ridge are very scarce; below we summarise the available evidence for eruption sites of contaminated lavas in central and eastern Disko and on Nuussuaq.

\section{Nordfjord Member}

Evidence for eruption sites and intrusions from the Nordfjord Member is particularly scarce because the chemical composition of many Nordfjord Member basalts is not readily distinguishable from other evolved basalts in the province. Only two possible eruption sites have been recognised east of the Gneiss Ridge, both in north-castern Disko.

A crater structure, interpreted as belonging to a NWtrending basaltic fissure eruption system, has been identificd by multi-model photogrammetry within Nordfjord Member lavas on the steep. inalcesssible mountain wall facing the Vaigat at Oullissaaqqat Oaqqarsuat (Fig. 2).

A composite lava flow with native iron, with a lower basaltic and an upper more silica-cnriched part, occurs 
Table 1. Representative analyses of lavas from the Maligât Formation in eastern Nuussuaq, and of dykes correlated with the Niaqussat Member in eastern Disko

\begin{tabular}{|c|c|c|c|c|c|c|c|c|}
\hline GGU No. & 332885 & 332882 & 332859 & 332860 & 332895 & 332893 & 362140 & 318824 \\
\hline $\mathrm{SiO}_{2}$ & 49.22 & 48.18 & 46.85 & 46.69 & 49.42 & 47.37 & 51.16 & 48.23 \\
\hline $\mathrm{TiO}_{2}$ & 1.97 & 1.49 & 1.14 & 1.26 & 2.31 & 3.90 & 1.57 & 1.35 \\
\hline $\mathrm{Al}_{2} \mathrm{O}_{3}$ & 14.34 & 14.82 & 12.15 & 12.71 & 13.44 & 12.85 & 13.49 & 13.24 \\
\hline $\mathrm{Fe}_{2} \mathrm{O}_{3}$ & 6.09 & 3.85 & 1.68 & 0.94 & 7.24 & 7.23 & 1.48 & 2.14 \\
\hline $\mathrm{FeO}$ & 6.40 & 6.90 & 8.55 & 9.34 & 6.69 & 8.24 & 8.33 & 8.45 \\
\hline $\mathrm{MnO}$ & 0.20 & 0.17 & 0.16 & 0.17 & 0.20 & 0.23 & 0.15 & 0.17 \\
\hline $\mathrm{MgO}$ & 6.67 & 8.40 & 14.53 & 13.70 & 5.85 & 5.63 & 9.57 & 12.64 \\
\hline $\mathrm{CaO}$ & 11.41 & 11.79 & 9.15 & 9.61 & 10.25 & 9.88 & 9.07 & 10.05 \\
\hline $\mathrm{Na}_{2} \mathrm{O}$ & 2.35 & 2.01 & 1.26 & 1.42 & 2.36 & 2.35 & 1.99 & 1.63 \\
\hline $\mathrm{K}_{2} \mathrm{O}$ & 0.18 & 0.14 & 0.18 & 0.34 & 0.43 & 0.44 & 0.22 & 0.14 \\
\hline $\mathrm{P}_{2} \mathrm{O}_{5}$ & 0.16 & 0.12 & 0.10 & 0.11 & 0.23 & 0.42 & 0.18 & 0.15 \\
\hline \multirow[t]{2}{*}{ Volat. } & 0.82 & 1.48 & 4.36 & 3.52 & 1.02 & 0.97 & 2.97 & 1.39 \\
\hline & 99.81 & 99.35 & 100.11 & 99.81 & 99.44 & 99.51 & 100.18 & 99.58 \\
\hline$m g$ number & 0.532 & 0.621 & 0.745 & 0.731 & 0.473 & 0.436 & 0.667 & 0.711 \\
\hline \multicolumn{9}{|c|}{ Trace elements, ppm } \\
\hline $\mathrm{V}$ & 342 & 303 & 190 & 254 & 406 & 368 & 260 & 275 \\
\hline $\mathrm{Cr}$ & 106 & 326 & 1107 & 888 & 100 & 141 & 575 & 838 \\
\hline $\mathrm{Ni}$ & 76 & 132 & 429 & 333 & 58 & 67 & 152 & 295 \\
\hline $\mathrm{Cu}$ & 216 & 126 & 85 & 72 & 183 & 271 & & 85 \\
\hline $\mathrm{Zn}$ & & 81 & & 86 & 118 & 120 & & 83 \\
\hline $\mathrm{Sc}$ & & 33 & & 26 & 39 & 37 & & 29 \\
\hline $\mathrm{Ga}$ & & 20 & & 16 & 23 & 28 & & 20 \\
\hline $\mathrm{Rb}$ & & 0.7 & & 6.9 & 12 & 7.9 & & 0.8 \\
\hline $\mathrm{Ba}$ & & 59 & & 84 & 112 & 230 & & 57 \\
\hline $\mathrm{Sr}$ & 215 & 182 & 257 & 210 & 180 & 211 & 211 & 187 \\
\hline $\mathrm{Y}$ & & 24 & & 19 & 40 & 58 & & 21 \\
\hline $\mathrm{Zr}$ & & 74 & & 74 & 145 & 251 & & 85 \\
\hline $\mathrm{Nb}$ & & 6.0 & & 3.7 & 8.5 & 22 & & 4.9 \\
\hline $\mathrm{La}$ & & 4 & & 3 & 10 & 15 & & 3 \\
\hline $\mathrm{Ce}$ & & 7 & & 10 & 20 & 53 & & 12 \\
\hline $\mathrm{Nd}$ & & 8 & & 9 & 18 & 45 & & 12 \\
\hline
\end{tabular}

Major elements by GGU's chemical laboratory (XRF except $\mathrm{Na}_{2} \mathrm{O}$ by AAS and $\mathrm{FeO}$ by titration. Volatiles = loss on ignition corrected for oxygen uptake due to oxidation of $\mathrm{FeO}$ ).

Trace elements in 332885,332859 and 362140 by GGU's chemical laboratory (XRF except Cu by AAS).

Trace elements in other samples by J. Bailey, Geological Institute, University of Copenhagen (XRF).

$m g$ number $=$ atomic $\mathrm{Mg} /\left(\mathrm{Mg}+\mathrm{Fe}^{2+}\right)$ calculated with $\mathrm{Fe}_{2} \mathrm{O}_{3} / \mathrm{FeO}$ (wt\%) adjusted to 0.15 .

\section{Notes on samples}

Profiles north of Nunavik, eastern Nuussuaq (Fig. 4), 70²9.3'-30.5'N, 52 $16^{\prime}-28^{\prime} \mathrm{W}$ :

332885: Uppermost lava in Rinks Dal Member, alt. $1625 \mathrm{~m}$.

332882: Lava from Nordfjord Member, alt. $1690 \mathrm{~m}$.

332859: Lower of two lavas from Niaqussat Member, alt. $1720 \mathrm{~m}$.

332860: Upper of two lavas from Niaqussat Member, alt. $1730 \mathrm{~m}$.

332895: Fifth lava in upper lava sequence, alt. $1945 \mathrm{~m}$.

332893: Seventh lava in upper lava sequence, alt. $2015 \mathrm{~m}$ (top lava).

Dykes correlated by chemical composition with Niaqussat Member:

362140: Sulphide- and iron-bearing dyke, $3 \mathrm{~m}$ wide, orientation $146^{\circ} / 80^{\circ} \mathrm{NE}$, Illukunnguaq, Disko, $69^{\circ} 53.1^{\prime} \mathrm{N}, 52^{\circ} 34^{\prime} \mathrm{W}$, alt. $75 \mathrm{~m}$.

318824: Dyke, $3.5 \mathrm{~m}$ wide, orientation $60^{\circ} / 78^{\circ} \mathrm{SE}$, Akunneq, Disko $69^{\circ} 49.2^{\prime} \mathrm{N}, 52^{\circ} 7^{\prime} \mathrm{W}$, alt. $2 \mathrm{~m}$. 


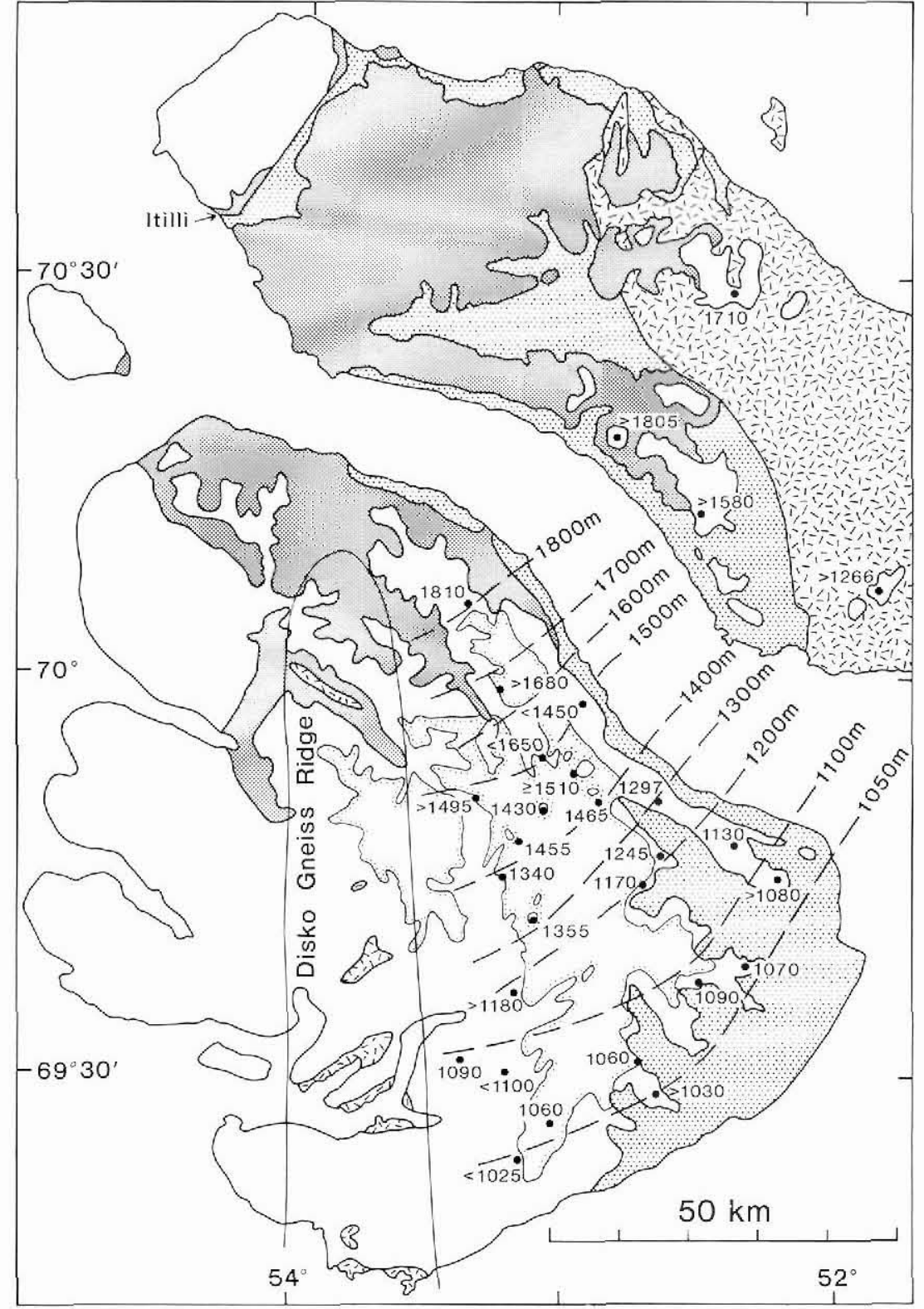

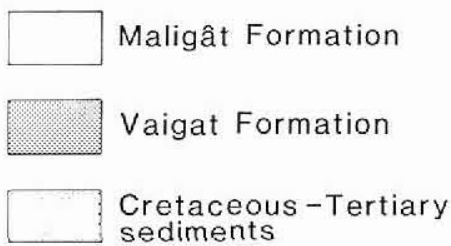

Basement Gneiss
Fig. 5. Contours for the base of the Niaqussat Member east of the Disko Gneiss Ridge and in eastern Nuussuaq. The areas west of the ridge are downfaulted. The contouring is based on the points shown. with heights or approximate heights in metres as indicated. in the Nordfjord Member in the Kvandalen area (Pedersen \& Larsen, 1987; Larsen \& Pedersen, 1989). The distribution of this lava flow constrains the eruption site to within the Kvandalen area, but the site itself has not been located

\section{Niaqussat Member}

The basalts from the Niaqussat Member are chemically distinctive because of their $\mathrm{MgO}$ and $\mathrm{SiO}_{2}$ contents (Pedersen, 1977b). Many rocks have higher $\mathrm{MgO}$ (and $m g$ numbers) than any other rocks from the Mali- gât Formation, and all rocks, including those with lower and more 'normal' $\mathrm{MgO}$ contents, have $\mathrm{SiO}_{2}$ contents $1-2 \%$ higher, or more, than in uncontaminated rocks with comparable $m g$ numbers. Most of the eruption sites and dykes of contaminated rocks west of the Disko Gneiss Ridge belong to the Niaqussaq Member.

East of the Disko Gneiss Ridge a probable feeder dyke for the Niaqussat Member occurs at the Vaigat coast at Illukunnguaq (Fig. 2). The dyke trends NW and consists of magnesian silicic basalt; it contains accumulations of nickeliferous pyrrhotite described by Pauly (1958) and native iron (Ulff-Møller, 1983). On the 
mountaintop Qinngusaq $5 \mathrm{~km} \mathrm{SW}$ of Illukunnguaq the Niaqussat Member includes a composite lava flow with native iron, and since such a lava does not flow very far from its eruption site the Illukunnguaq dyke very likely fed this lava. If this is true, then the pyrrhotite accumulation was formed $c .1250 \mathrm{~m}$ below the palaeosurface. A chemical analysis of the dyke is presented in Table 1 (column 7).

A search through existing analyses of dykes from eastern and southern Disko and Nuussuaq revealed an additional ten dykes of magnesian silicic basalt which may be correlated with the Niaqussat Member and hence may have been feeders for this member. All eleven localities are shown in Fig. 2. The dykes include two compositional types both of which have equivalents among the Niaqussat Member lavas; one contains $11-13 \% \mathrm{MgO}$ (Table 1, column 8) whereas the other contains $7.5-8 \% \mathrm{MgO}$. Both types occur in both eastern Disko and Nuussuaq. Most of them are hosted in sediments from the Cretaceous Atane Formation but a few were found cutting the Rinks Dal Member lavas. They have variable directions with a dominance of northeasterly orientations.

In summary, there is evidence for the presence of eruption sites for both the Nordfjord and Niaqussat Members on eastern Disko, and for the Niaqussat Member on south-eastern Nuussuaq.

\section{Discussion}

The smooth south-easterly-sloping surface defined by the base of the Niaqussat Member (Fig. 5) may be used in the reconstruction of the basin development in the Disko-Nuussuaq area. However, there are several possible interpretations of the origin of the present shape of the surface. A: the slope is post-volcanic and reflects late basin movements. B: the slope is synvolcanic and reflects basin movements during deposition of the lavas. $\mathrm{C}$ : the slope is synvolcanic and reflects greater volcanic productivity in the north-west than in the south-east. $\mathrm{D}$ : Any combination of A, B and C.

In order to differentiate between these possibilities the analysis of the shape of several successive surfaces or rock units within the whole volcanic and sedimentary sequence in the area is required. A few such analyses have been carried out and more are in progress. In the following the evidence is discussed chronologically, i.e. for successively younger rocks.

In the Vaigat Formation the second volcanic cycle, leading to the deposition of lavas and hyaloclastites of the Ordlingassoq Member (Fig. 1), started with a transgression. The shoreline of this transgression can be read from the 1:100 000 map sheets Qutdligssat and Agatdal (change from subaerial to hyaloclastite facies of the Ordlingassoq Member) and strikes roughly SW-NE across northern Disko and Nuussuaq. Thus, a relative subsidence of the south-eastern area at that time is indicated.

Piasecki et al. (1992) reported marine or brackish incursion in sediments just below or coeval with the lower part of the Rinks Dal Member in south-eastern Disko, whereas coeval sediments in south-eastern $\mathrm{Nu}$ ussuaq are non-marine. Again, a relative subsidence of the southern area at this time is indicated.

Heinesen (1987) studied thickness variations within some volcanic units from the lower part of the Rinks Dal Member along the south coast of Disko. He was able to demonstrate fairly continuous local subsidence of the areas east of the Disko Gneiss Ridge during deposition of these units.

Pedersen \& Ducholm (in press) studied one very extensive lava flow from the upper part of the Rinks Dal Member in south-eastern Nuussuaq. By quantitative photogrammetry they showed that the lava was erupted onto an essentially horizontal surface and later was inflected, with a relative subsidence of the south-eastern part and movements centred along a marked NE-trending flexure.

Within the Nordfjord Member in eastern Disko, Larsen \& Pedersen (1989) described rhyolite blocks transported by rivers more than $70 \mathrm{~km}$ eastwards from western Disko, showing that the palaeolandscape at that time had an easterly slope.

During deposition of the Niaqussat Member, thin fluid olivine microporphyritic lavas spread over an area of more than $10000 \mathrm{~km}^{2}$, indicating a flat palaeolandscape. The distribution of possible feeders to these lavas over a large area (Fig. 2) is in accordance with the wide distribution of the lavas. Any marked topographical relief and slope would have led to channelling and ponding of the flows which is not observed. Thus, it seems unlikely that the present slope of the base of the Niaqussat Member, with height differences of around $800 \mathrm{~m}$, is an original feature of this surface, and a later subsidence of the south-eastern area is suggested.

It can be concluded that considerable crustal movements took place concomitantly with the deposition of the volcanic rocks. The movements started no later than the time of beginning of the Ordlingassoq Member and continued until after the deposition of the Niaqussat Member. Relative subsidence in the south-east and uplift in the north-west is consistently indicated throughout this time. The occurrence of marine incursions in the south at a relatively late stage in the basin development suggests that the actual movement was tilting and not differential uplift. 
The recorded crustal movements could not have been caused by loading by the heavy volcanic rocks because this would produce movements opposite to those observed. There is a remarkable parallelism between the height contours in Fig. 5 and the direction of the NE-SW striking Itilli fault on western Nuussuaq which may represent a landward extension of the Ungava transcurrent fault system in the Davis Strait (J. A. Chalmers, unpublished data). The crustal movements may be caused by large-scale plate tectonic processes and reflect lithospheric thinning with subsidence in the south-east in combination with uprise and melting of mantle material at the site of the subsequently formed continental margin in the north-west.

\section{References}

Dueholm, K. S. \& Pedersen, A. K. 1988: Geological photogrammetry using oblique aerial photographs. Rapp. Grønlands geol. Unders. 140, 33-38.

Hald, N. 1976: Early Tertiary flood basalts from Hareøen and western Nûgssuaq, West Greenland. Bull. Grønlands geol Unders. 120, $36 \mathrm{pp}$.

Heinesen, M. 1987: Nedre Tertiære basaltbreccier og undervands-lavastrømme, sydlige Disko, Vestgrønland: Strukturelle, petrografiske og mineralogiske studier. Cand. scient thesis, University of Copenhagen, 4 vols, $118 \mathrm{pp}$ txt.

Larsen, L. M. \& Pedersen, A. K. 1988: Investigations of Tertiary volcanic rocks along the south coast of Nûgssuaq and in eastern Disko, 1987. Rapp. Grønlands geol. Unders. 140, 28-32.

Larsen, L. M. \& Pedersen, A. K. 1989: New geological investigations in eastern Disko: redeposited volcanoclastic sediments with rhyolite from the Nordfjord Member. Rapp. Grønlands geol. Unders. 145, 45-49.

Larsen, L. M. \& Pedersen, A. K. 1990: Volcanic marker horizons in the Maligât Formation on Disko and Nûgssuaq, and implications for the development of the southern part of the West Greenland basin in the early Tertiary. Rapp. Grønlands geol. Unders. 148, 65-73.

Pauly, H. 1958: Igdlukúnguaq nickeliferous pyrrhotite. Bull. Grønlands geol. Unders. 17, 169 pp. (Also Meddr Grønland 157, 3.)

Pedersen, A. K. 1975: New mapping in north-western Disko 1972. Rapp. Grønlands geol. Unders. 69, 25-32.

Pedersen, A. K. 1977a: Iron-bearing and related volcanic rocks in the area between Gieseckes Dal and Hammers Dal, north-west Disko. Rapp. Grønlands geol. Unders. 81, 5-14.

Pedersen, A. K. 1977b: Tertiary volcanic geology of the Mellemfjord area, south-west Disko. Rapp. Gronlands geol. Unders. 81, 35-51.

Pedersen, A. K. 1977c: Dyke intrusions along the south coast of Disko. Rapp. Grønlands geol. Unders. 81, 57-67.

Pedersen, A. K. 1985: Lithostratigraphy of the Tertiary Vaigat Formation on Disko, central West Greenland. Rapp. Grønlands geol. Unders. 124, $30 \mathrm{pp}$.

Pedersen, A. K. \& Dueholm, K. in press: New methods for the geological analysis of Tertiary volcanic formations on Nuussuaq and Disko, central West Greenland, using multi-model photogrammetry. Rapp. Grønlands geol. Unders. 156.

Pedersen, A. K. \& Larsen, L. M. 1987: Early Tertiary volcanic rocks from eastern Disko and south-eastern Nûgssuaq. Rapp. Grønlands geol. Unders. 135, 11-17.

Piasecki, S., Larsen, L. M., Pedersen, A. K. \& Pedersen, G. K. 1992: Palynostratigraphy of the Lower Tertiary volcanics and marine clastic sediments in the southern part of the West Greenland Basin: implications for the timing and duration of the volcanism. Rapp. Grønlands geol. Unders. 154, 13-31.

Ulff-Møller, F. 1977: Native iron bearing intrusions of the Hammers Dal complex, north-west Disko. Rapp. Grønlands geol. Unders. 81, 15-33.

Ulff-Møller, F. 1983: Tellurisk jern fra subvulkanske intrusioner på Disko, Grønland. Ph.D. thesis, University of Copenhagen, 209 pp

Ulff-Møller, F. 1991: Magmatic platinum-nickel occurrences in the Tertiary West Greenland Basalt Province: prospecting by Greenex A/S in 1985-1988. Open File Ser. Grønlands geol. Unders. 91/2, $36 \mathrm{pp}$. 